\title{
Extensor tendon traumatic gap reconstruction
}

\author{
Tolga Turker \\ From 10th Congress of the Asia-Pacific Federation of Societies of Surgery fo the Hand and the 6th Congress \\ of Asia-Pacific Federation of Societies of Hand Therapists \\ Kuala Lumpur, Malaysia. 2-4 October 2014
}

Repair of extensor tendon defects or gap injuries often require complicated surgical techniques. Unlike flexor tendons, which have good excursion that can help mobilize the flexor tendon allowing for repair of up to $1 \mathrm{~cm}$ gaps, extensor tendons only have 1-2 mm of excursion, especially in Verdan's extensor Zones 1 to 5. Furthermore, a $1-\mathrm{mm}$ tendon gap in Zones 1 to 5 may cause 20 degrees extension loss or shortening of the extensor tendon, and a gap even as small as $1 \mathrm{~mm}$ may cause decreased finger flexion. Due to such significant potential damage and loss of function caused by extensor tendon defect injuries, especially in Zones 1-5, solutions most often require some type of reconstruction techniques.

\section{The zone 1}

According to the size of defects three major reconstruction techniques may be used. Terminal tendon hemilateral band technique; This technique uses the lateral bands of the same injured fingers to bridge the gap formation. This technique requires temporary fixation distal interphalaheal joint (DIPJ) with a $\mathrm{K}$ wire for 4 weeks. After the wire removal, an aluminum splint is used for following 2 more weeks with occupational therapy (OT).

Interpostional tendon grafting; This technique requires a free tendon harvesting in order to reconstruct the extensor tendon defects. The Palmaris longus tendon is sutured to the distal phalanx then the tendon sutured to the proximal part of the extensor tendon that is being reconstructed and the DIPJ is immobilized in 0-15 degrees hyperextension for 4weeks then OT is started. If there is soft tissue defect with tendon loss, composite tissue, using palmarislongus and skin island as Inoue et al. reported. Wavreille et al. demonstrated in a cadaveric study that uses second toe extensor apparatus with skin island that's blood is supplied by the first dorsal metatarsal artery.
Tendon transplantation and allograft; If there is an injury that involves more then one finger, one finger has tendon defect in zone 1 or 2 with good condition of DIPJ and PIPJ and the other finger or fingers have severe injury that requires either DIPJ either needs fusion or amputation, this finger(s)'s terminal tendon can be harvested to reconstruct the defect in extensor tendon. It is also possible to use allograft as a tendon resource.

\section{The zone 2}

Zone 2 defects show similarities to the zone 1 defects. Again local tendon grafts and free interpositional tendon reconstructions may be considered.

Local tendon grafts; Kochevar et al.'s cadaveric study uses $0.5 \mathrm{~cm}$ defect, which can be bridge with preparation of tendon graft from proximal portion and flip over to reconstruct the gap.

Interpositional tendon grafts; Similar to the zone 1 extensor tendon defects, PL tendon may be used to reconstruct the zone 2 defects.

\section{The zone 3}

This zones defects are important because they may cause boutonnière deformity. Therefore reconstruction is important not only overcome the defect but also prevent the boutonnière deformity.

If lateral bands and/or proximal portion of the tendon are intact, one of two techniques can be used. First, the lateral bands can be divided longitudinally and centered over the PIP joint and sutured to each other. Second, a distal based tendon flap can be created using the proximal of tendon and flip over to distally to overcome the defect as Kochevar described in their cadaveric study.

Again, composite tissue, Palmaris longus and venous island flaps can be used to reconstruct the extensor tendon defects in zone 3. 


\section{The zones 4 and 5}

In this zone, there is more tendon substance then other zones, therefore reconstruction of tendon gaps could be relatively easier. Again, two major reconstructions techniques should be in mind. Local tendon flaps and interpositional free tendon reconstructions.

like in zone 2, Kochevar et al. reported local tendon graft technique that can bridge $1 \mathrm{~cm}$ tendon defects without repair site suture failure with maximum IP and MP joint flexion.

Interpostional tendon reconstructions also another solution to overcome tendon defects in zone 4 defects. $\mathrm{PL}$ tendon is again, frequently used as a tendon graft in those defects. If there is a skin defect, composite venous flaps and PL tendon reconstruction could be an alternative procedure to fix gap formation in this zone.

\section{The zones 6, 7 and 8}

If adjacent tendons are in continuity, the distal end of the defective tendon maybe sutured to neighbor tendon side to side fashion in order to get the intact tendons motor power.

Interpostional tendon grafting: PL tendon can be used to reconstruct the extensor tendon in these zones. The tendons are generally sutured using the Pulvertaft technique which allows early rehabilitation. If there is any skin defects, as Scheker et al reported, tendon reconstruction may be combined with either lateral arm or groin flaps for coverage.

Published: 19 May 2015

\section{References}

1. Elliott RA Jr: Injuries to the extensor mechanism of the hand. Orthop Clin North Am 1970, 1(2):335-354.

2. Kochevar A, Rayan G, Angel M: Extensor tendon reconstruction for zones II and IV using local tendon flap: a cadaver study. J Hand Surg Am 2009, 34(7):1269-1275.

3. Savvidou C, Thirkannad S: Hemilateral band technique for reconstructing gap defects in the terminal slip of the extensor tendon. Tech Hand Up Extrem Surg 2011, 15(3):177-181.

4. Gu YP, Zhu SM: A new technique for repair of acute or chronic extensor tendon injuries in zone 1. J Bone Joint Surg Br 2012, 94(5):668-670.

5. Nichols HM: Repair of extensor-tendon insertions in the fingers. $J$ Bone Joint Surg Am 1951, 33-A(4):836-841.

6. Inoue G, Tamura $Y$, Suzuki K: One-stage repair of skin and tendon digital defects using the arterialized venous flap with palaaaris longus tendon: An additional four cases. J Reconstr Microsurg 1996, 12(2):93-97.

7. Lin CH, Wei FC, Lin YT, Chen CT: Composite palmaris longus-venous flap for simultaneous reconstruction of extensor tendon and dorsal surface defects of the hand - Long-term functional result. J Trauma 2004, 56(5):1118-1122.

8. Wavreille G, Cassio JB, Chantelot C, Mares O, Guinand R, Fontaine C: Anatomical bases of the second toe composite dorsal flap for simultaneous skin defect coverage and tendinous reconstruction of the dorsal aspect of the fingers. J Plast Reconstr Aesthet Surg 2007, 60(7):710-719.

9. Türker T, Capdarest-Arest N, Schmahl DT: Zone I extensor reconstruction with tendon salvaged from another finger. J Hand Surg Am 2014, 39(5):976-980.
10. Rockwell WB, Butler PN, Byrne BA: Extensor tendon: anatomy, injury, and reconstruction. Plast Reconstr Surg 2000, 106(7):1592-1603, quiz 1604, 1673.

11. Karacaoglu E, Gokce A: Perforator-based reverse radial forearm flap to reconstruct multiple third-degree burn defects of the fingers. J Burn Care Res 2008, 29(2):398-402.

12. Mountney J, Blundell CM, McArthur P, Stanley D: Free tendon interposition grafting for the repair of ruptured extensor tendons in the rheumatoid hand. A clinical and biomechanical assessment. In J Hand Surg Br. Volume 23. Edinburgh, Scotland; 1998:(5):662-665.

13. Chu PJ, Lee HM, Hou YT, Hung ST, Chen JK, Shih JT: Extensor-tendons reconstruction using autogenous palmaris longus tendon grafting for rheumatoid arthritis patients. J Orthop Surg 2008, 3:16.

14. Bora FW Jr, Osterman AL, Thomas VJ, Maitin EC, Polineni S: The treatment of ruptures of multiple extensor tendons at wrist level by a free tendon graft in the rheumatoid patient. J Hand Surg Am 1987, 12(6):1038-1040.

15. Nakamura S, Katsuki M: Tendon grafting for multiple extensor tendon ruptures of fingers in rheumatoid hands. In J Hand Surg Br. Volume 27. Edinburgh, Scotland; 2002:(4):326-328.

16. Lohman R, Evans GR: Malignant fibrous histiocytoma of the hand: Multimodal therapy and extensor tendon reconstruction. Ann Plast Surg 1998, 41(5):544-549.

17. Scheker LR, Langley SJ, Martin DL, Julliard KN: Primary extensor tendon reconstruction in dorsal hand defects requiring free flaps. In $J$ Hand Surg Br. Volume 18. Edinburgh, Scotland; 1993:(5):568-575.

18. Cerovac S, Miranda BH: Tendon 'turnover lengthening' technique. J Plast Reconstr Aesthet Surg 2013, 66(11):1587-1590.

19. Brand PW, Beach RB, Thompson DE: Relative tension and potential excursion of muscles in the forearm and hand. J Hand Surg Am 1981, 6(3):209-219.

doi:10.1186/1753-6561-9-S3-A69

Cite this article as: Turker: Extensor tendon traumatic gap reconstruction. BMC Proceedings 2015 9(Suppl 3):A69.

\section{Submit your next manuscript to BioMed Central and take full advantage of:}

- Convenient online submission

- Thorough peer review

- No space constraints or color figure charges

- Immediate publication on acceptance

- Inclusion in PubMed, CAS, Scopus and Google Scholar

- Research which is freely available for redistribution 